\title{
NITROGEN IN THE PRODUCTION OF GREEN AND DRY MASS AND THE EFFICIENCY OF NITROGEN CONVERSION AND APPARENT RECOVERY OF PEARL MILLET CULTIVARS
}

\author{
NITROGÊNIO NA PRODUÇÃO DE MASSA VERDE E SECA, EFICIÊNCIA DE \\ CONVERSÃO E RECUPERAÇÃO APARENTE DO NITROGÊNIO DE CULTIVARES \\ DE MILHETO
}

\section{Wilian Henrique Diniz BUSO ${ }^{1}$; Aldi Fernandes de Souza FRANÇA ${ }^{2}$; Eliane Sayuri MIYAGI ${ }^{2}$; Daniel Staciarini CORRÊA ${ }^{3}$}

1. Professor, Doctor, Department of Agriculture and Animal Science - Goiano Federal Institute - IF Goiano, Campus Ceres, Ceres, GO, Brazil. wilian.buso@ifgoiano.edu.br; 2. Professor, Doctor, Department of Animal Prduction, School of Veterinary and Animal Science Federal University of Goiás - UFG, Goiânia, GO, Brazil; 3. Animal Scientist, PhD student, School of Veterinary and Animal Science Federal University of Goiás - UFG, Goiânia, GO, Brazil

\begin{abstract}
The potential of dry (DM) and green (GM) matter yield, plant nitrogen concentration (NC), apparent nitrogen conversion efficiency (NCE) and apparent $\mathrm{N}$ recovery (ANR) of pearl millet cultivars with nitrogen fertilization are analyzed. Current experiment was conducted in the municipality of Ceres GO Brazil, within the Cerrado (Brazilian savannah) biome. A 3x4x2 randomized factorial block design was employed, with three repetitions. Treatments were composed of three pearl millet cultivars (ADR-7010, ADR-500 and BRS-1501), four N doses (0, 50, 100 and $200 \mathrm{~kg}$ $\mathrm{ha}^{-1}$ ) and two sowing times (December and February). Plants from each seeding were harvested twice at a height of 0.70 $\mathrm{m}$. There was a significant effect on the interaction between cultivars and $\mathrm{N}$ doses. GM yield of ADR-7010 cultivar increased up to $140 \mathrm{~kg} \cdot \mathrm{ha}^{-1}$ of $\mathrm{N}$. There was a quadratic effect of $\mathrm{N}$ doses on DM yield, with maximum production at 158 $\mathrm{kg} \mathrm{ha}^{-1} \mathrm{~N}$. The quantity of $\mathrm{N}$ extracted by the plants varied according to the cultivar, with BRS-1501 accumulating the highest $\mathrm{N}$ quantities in the shoots. Maximum NC of pearl millet shoots would be achieved with $147 \mathrm{~kg} \mathrm{~N} \mathrm{ha}^{-1}$. The highest NCE occurred with $\mathrm{N}$ doses of $50 \mathrm{~kg} \mathrm{ha}^{-1}$, with a DM yield of $11.60 \mathrm{~kg}$ per kg of applied $\mathrm{N}$. ANR was also highest for $\mathrm{N}$ doses of $50 \mathrm{~kg} \mathrm{ha}^{-1}$, with a $53 \%$ maximum recovery.
\end{abstract}

KEYWORDS: Sowing time. Forage. Pennisetum glaucum. Urea.

Abbreviations: ANR, apparent nitrogen recovery; CP, crude protein; DM, dry matter; GM, green matter; NC, plant nitrogen concentration; NCE, apparent nitrogen conversion efficiency.

\section{INTRODUCTION}

Cattle-breeding in Brazil is mainly based on pasture as opposed to grain-feeding, for lower costs. However, animal productivity indexes in the savannah biome are low owing to the degradation of many areas and to the low technological level of herd management, with high liabilities in potential earnings.

Pearl millet (Pennisetum glaucum (L.) R. Brown), an annual plant with high nutrition rates, may be used for grain production, mulching and forage for grazing and production of silage. Due to its physiological characteristics, pearl millet is highly resistant to water stress and adapts well to acidic and low-fertility soils which are limiting factors for corn (Pires et al., 2007). Results obtained by Pires et al. (2007) demonstrate that the dry matter yield (DM) of three pearl millet cultivars increased as the plants attained full flowering and reached $19.29 \mathrm{tha}^{-1}$ of DM.
Nitrogen $(\mathrm{N})$ availability is one of the most important factors in the growth and development of plants. Increase in $\mathrm{N}$ contents of the soil by fertilization is one of the main strategies to boost forage plant yields (MARTUSCELLO et al., 2005).

According to Fagundes et al. (2006), the supply of adequate quantities of $\mathrm{N}$ during the development of forage plants is fundamental for the growth of pastures since $\mathrm{N}$ available from the mineralization of organic matter does not supply the needs of high-yield forage plants. Increased nitrogen fertilization raised DM production of Mombasa grass in the rainy and dry seasons. In fact, the average $\mathrm{N}$ dose of $307 \mathrm{~kg} \mathrm{ha}^{-1}$ was highly efficient for the conversion of nitrogen fertilizer by the grass (Mello et al., 2008).

In their study on forage pearl millet, Mesquita and Pinto (2000) reported that N influenced DM yield, with a quadratic regression curve best fitting the data, according to which maximum yield of $8,913 \mathrm{~kg} \mathrm{ha}^{-1}$ was reached with a 
maximum $\mathrm{N}$ dose of $139 \mathrm{~kg} \mathrm{ha}^{-1}$. Heringer and Moojen (2002) noted that DM production of pearl millet responded quadratically to nitrogen fertilization and also verified that the efficiency of the use and recovery rates of $\mathrm{N}$ declined as $\mathrm{N}$ doses increased.

We aimed to evaluate green and dry matter forage yield as well as the efficiency of apparent nitrogen conversion (NCE), apparent $\mathrm{N}$ recovery (ANR) and $\mathrm{N}$ concentration (NC) of three pearl millet cultivars with four $\mathrm{N}$ doses at two sowing times, on the Brazilian savannah Biome.

\section{MATERIAL AND METHODS}

The experiment was conducted on the experimental farm of the Instituto Federal Goiano, Ceres Campus, in the municipality of Ceres GO Brazil, at $15^{\circ} 21^{\prime} 00^{\prime \prime} \mathrm{S}$ and $49^{\circ} 35^{\prime} 57^{\prime \prime} \mathrm{W}$, altitude $564 \mathrm{~m}$. The region's climate is Aw, according to Köeppen classification, or rather, hot and semihumid with well-defined wet and dry seasons. The average annual rainfall is $1550 \mathrm{~mm}$, with the rainy season running from October to April and the dry season from May to September. Figure 1 shows monthly rainfall and average temperatures during the experiment period.

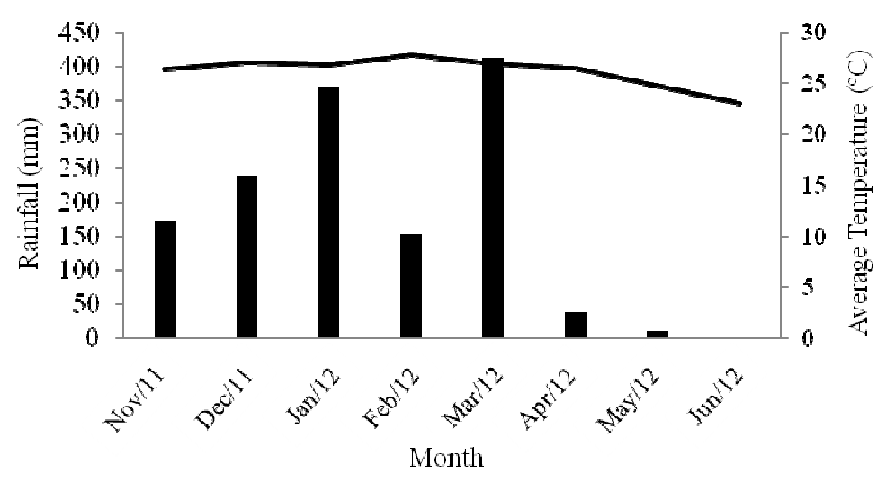

Figure 1. Monthly rainfall $(\mathrm{mm})$ and average temperature $\left({ }^{\circ} \mathrm{C}\right)$ during the experimental period (November 2011 to June 2012).

Source: Weather season from IF Goiano Campus Ceres.

The soil in the experimental area has been classified as dystrophic red Latosol (Embrapa, 2006). Samples were collected from the top layer (0 to $20 \mathrm{~cm}$ ) for chemical and physical characterization. The results were $\mathrm{Ca}: 2.4 ; \mathrm{Mg}: 1.3$; CTC: 7.67; Al: 0; $\mathrm{H}: 3.7\left(\mathrm{cmol}_{\mathrm{c}} \mathrm{dm}^{-3}\right)$; P (Melich): 5.0; $\mathrm{K}: 101\left(\mathrm{mg} \mathrm{dm}^{-3}\right), \mathrm{pH}\left(\mathrm{CaCl}_{2}\right)$ : 5.6, saturation bases: 51.8 ; organic matter: 1.5 ; sand: 39 ; clay: 50 $(\%)$. Soil in the experimental field was prepared conventionally with two passages of a disk harrow followed by one with a leveling harrow on the day before sowing.

Treatments were composed of three pearl millet cultivars (ADR-7010, ADR-500 and BRS $1501)$, four $\mathrm{N}$ doses $\left(0,50,100\right.$ and $\left.200 \mathrm{~kg} \mathrm{~N} \mathrm{ha}^{-1}\right)$ and two sowing times (December 2010 and February 2011). The experimental design consisted of fully randomized blocks in a $3 \times 4 \times 2$ factorial scheme, with three replications, for a total of 72 experimental units.

The seeds were planted manually on December 1, 2010 and on February 20, 2011. Each experimental plot was composed of four rows, 5 meters in length, spaced $0.30 \mathrm{~m}$ apart, covering an area of $4.5 \mathrm{~m}^{2}$. The seeds were planted at a density of 20 pure viable seeds per meter. Forty-five $\mathrm{kg}$ $\mathrm{P}_{2} \mathrm{O}_{5}$ ha $^{-1}$ (simple phosphate) was applied in the furrows at the time of sowing. Ten days after germination, potassium was applied at $30 \mathrm{~kg} \mathrm{ha}^{-1}$ $\mathrm{K}_{2} \mathrm{O}$ (potassium chloride) as top dressing. Nitrogen fertilizer (urea) was also applied, in two portions, or rather, $60 \%$ ten days after germination and the remaining $40 \%$ the day after the harvest for the first evaluation.

The plant's material samples were taken from the two central rows, eliminating the last 0.50 $\mathrm{m}$ at the two ends (two rows measuring $4 \mathrm{~m}$ in length). The plants from each sowing time were harvested twice, on the $5^{\text {th }}$ and $27^{\text {th }}$ January 2011 for the first and on the $27^{\text {th }}$ March and $21^{\text {st }}$ April 2011 for the second. They were harvested when at least $50 \%$ of the plants were $0.70 \mathrm{~m}$ high. After each harvest, the material was weighed to determine green matter yield $\left(\mathrm{GM}\right.$ in $\left.\mathrm{kg} \mathrm{ha}^{-1}\right)$. Total GM was the sum of the two harvests.

Samples of approximately $500 \mathrm{~g}$ were used for laboratory analyses. The samples were dried for 72 hours in a forced-air chamber at $60^{\circ} \mathrm{C}$ to 
determine dry matter (DM) yield. They were then ground in a Wiley mill and passed through a $1 \mathrm{~mm}$ sieve. The ground material was stored in duly identified acrylic flasks and shut with plastic lids. The samples from the two harvests within the respective sowing groups were mixed and homogenized for subsequent laboratory analyses. The material from the two harvests was not evaluated individually because the second harvest was influenced by the first portion of the nitrogen fertilization.

The plant's dry matter (DM) and $\mathrm{N}$ concentration (NC) rates, determined according to method described by Silva and Queiroz (2002), were performed at the Animal Nutrition Laboratory of the Animal Production Department of the Veterinary School of Goiás Federal University.

Since nitrogen in roots and residue was not measured, the recovery of $\mathrm{N}$ absorbed from the total applied only took into account the shoots' NC. Nitrogen conversion efficiency (NCE) and apparent nitrogen recovery (ANR) were determined following Carvalho and Saraiva (1987).

Data on GM and DM yield, NC, crude protein (CP), NCE and ANR were submitted to joint analysis of variance; the two sowing times and mean rates were compared by Tukey's test at 5\%
BUSO, W. H. D. et al.

significance. Variables were also evaluated by fitting regression equations as a function of $\mathrm{N}$ dose applied as top dressing. The statistical analysis was performed with R software ( $\mathrm{R}$ Development Core Team, 2010).

\section{RESULTS}

The interaction between cultivars and nitrogen doses provided significant effects $(\mathrm{p}<0.05)$, with different responses of the cultivars to different $\mathrm{N}$ doses for GM yield. There was no significant interaction ( $p>0.05)$ between cultivars and $\mathrm{N}$ doses, sowing time and $\mathrm{N}$ doses and cultivars and sowing times and also between the triple interaction of time, cultivar and $\mathrm{N}$ dose for the variables $\mathrm{DM}, \mathrm{CP}, \mathrm{NC}$, NCE and ANR.

Table 1 shows significant interaction $(p<0.05)$ between cultivars and $\mathrm{N}$ doses. All the pearl millet cultivars were significantly affected by the application of nitrogen: increasing $\mathrm{N}$ caused an increase in the GM yield of the cultivars. Regression analysis demonstrated that GM yield of cultivars ADR 7010 and BRS 1501 responded quadratically to increased nitrogen doses (Figure 2).

Table 1. Green matter (GM) of pearl millet cultivars $\left(\mathrm{kg} \mathrm{ha}^{-1}\right)$ with increasing nitrogen doses.

\begin{tabular}{lcccc}
\hline \multirow{2}{*}{ Cultivar } & \multicolumn{4}{c}{ Nitrogen Doses $\left(\mathrm{kg} \mathrm{ha}^{-1}\right)$} \\
\cline { 2 - 5 } & 0 & 50 & 100 & 200 \\
\hline ADR -7010 & $26,650 \mathrm{a}$ & $27,550 \mathrm{a}$ & $34,830 \mathrm{a}$ & $32,010 \mathrm{~b}$ \\
ADR -500 & $26,890 \mathrm{a}$ & $28,280 \mathrm{a}$ & $33,240 \mathrm{a}$ & $33,780 \mathrm{ab}$ \\
BRS -1501 & $21,370 \mathrm{a}$ & $29,060 \mathrm{a}$ & $35,290 \mathrm{a}$ & $38,490 \mathrm{a}$ \\
\hline
\end{tabular}

Means followed by the same small letters in the columns do not differ statistically by Tukey's test at 5\% probability.

In the case of ADR 7010, the maximum GM yield $\left(34,522.1 \mathrm{~kg} \mathrm{ha}^{-1}\right)$ would be achieved with 140 $\mathrm{kg} \mathrm{N} \mathrm{ha}^{-1}$. For BRS 1501, the application of $184 \mathrm{~kg}$
$\mathrm{N}^{-1}$ would produce $38,663.7 \mathrm{~kg} \mathrm{GM} \mathrm{ha}^{-1}$ (Figure 2), whereas cultivar ADR 500 demonstrated linear response to nitrogen application.

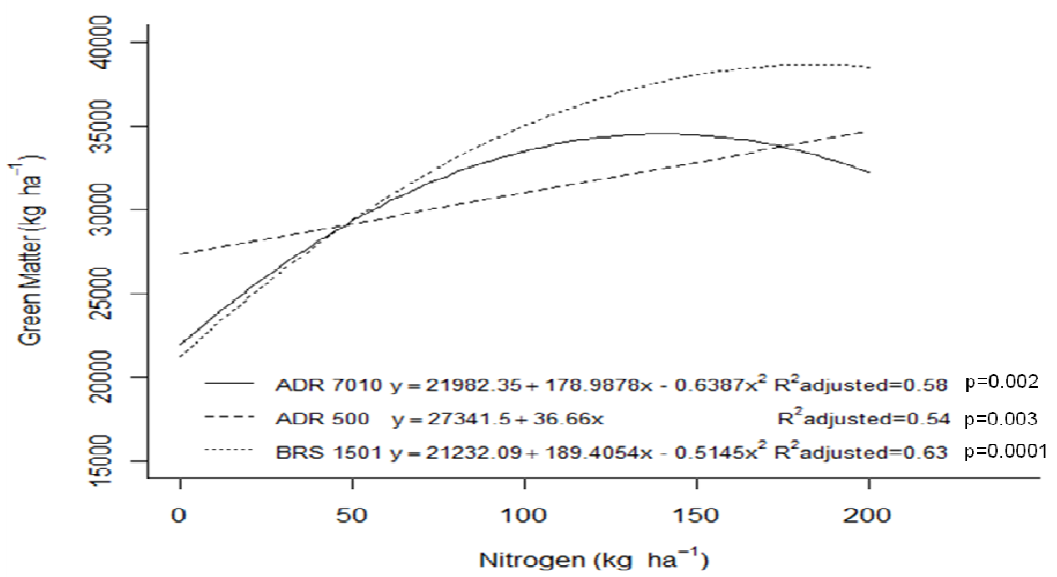

Figure 2. Green matter yield of pearl millet cultivars in response to nitrogen application. 
Table 2 shows GM and DM yields produced by plants according to sowing time. There were significant differences $(p<0.05)$ for $G M$ and $D M$ yield between the two groups. Plants' yield from seeds sown in December was higher due to better climate conditions, mainly water availability. On the other hand, less water availability in February and average lower temperature were factors that tended to reduce GM production.

Table 2. Total production of green (GM) and dry (DM) matter for the three pearl millet cultivars at two sowing times, December 2010 and February 2011.

\begin{tabular}{lll}
\hline Sowing Time & $\mathrm{GM}\left(\mathrm{kg} \mathrm{ha}^{-1}\right)$ & $\mathrm{DM}\left(\mathrm{kg} \mathrm{ha}^{-1}\right)$ \\
\hline December & $34,198.31 \mathrm{a}$ & $3,446.65 \mathrm{a}$ \\
February & $26,376.56 \mathrm{~b}$ & $2,750.85 \mathrm{~b}$ \\
\hline $\mathrm{CV}(\%)$ & 10.67 & 14.32 \\
\hline
\end{tabular}

Means followed by the same letters in the columns are statistically the same by Tukey's test at $5 \%$ probability.

There were no significant interactions ( $\mathrm{p}>0.05$ ) between cultivars and $\mathrm{N}$ doses for $\mathrm{DM}$ production, but there was a significant difference in
DM yield between cultivars $(\mathrm{p}<0.05)$, as Table 3 shows.

Table 3. Mean rates of dry matter (DM) yield of pearl millet according to cultivar and nitrogen doses determined for the two sowing times.

\begin{tabular}{ll}
\hline Cultivar & $\mathrm{DM}\left(\mathrm{kg} \mathrm{ha}^{-1}\right)$ \\
\hline ADR-7010 & $2,560.63 \mathrm{c}$ \\
ADR-500 & $3,205.25 \mathrm{~b}$ \\
BRS-1501 & $3,530.38 \mathrm{a}$ \\
\hline CV $(\%)$ & 14.32 \\
\hline
\end{tabular}

Means followed by the same letter in the columns do not differ statistically by Tukey's test at 5\% probability.

There was a significant difference $(\mathrm{p}<0.05)$ between nitrogen concentrations (NC) and crude protein $(\mathrm{CP})$ for sowing time, cultivar and $\mathrm{N}$ dose. In plants sown on December 2010, there was a $124.49 \mathrm{~kg} \mathrm{ha}^{-1}$ of $\mathrm{N}$ accumulation in the shoots and $\mathrm{CP}$ production was $778.07 \mathrm{~kg} \mathrm{ha}^{-1}$, while those planted on February 2011 accumulated $92.12 \mathrm{~kg} \mathrm{ha}^{-1}$ of $\mathrm{N}$ and produced $575.77 \mathrm{~kg} \mathrm{ha}^{-1}$ of $\mathrm{CP}$.
$\mathrm{N}$ quantity extracted by the plants and $\mathrm{CP}$ varied according to the cultivar. As Table 4 demonstrates, cultivar BRS-1501 accumulated higher amounts of $\mathrm{N}$ in the shoots and also produced more CP. This latter factor was related to DM yield, since cultivar BRS-1501 had the highest productivity. NC and $\mathrm{CP}$ rates increased up to 147 $\mathrm{kg} \mathrm{N}$ ha $^{-1}$.

Table 4. Mean rates of nitrogen concentration (NC) and crude protein (CP) of pearl millet cultivars submitted to nitrogen doses

\begin{tabular}{lll}
\hline Cultivar & $\mathrm{NC}\left(\mathrm{kg} \mathrm{ha}^{-1}\right)$ & $\mathrm{CP}\left(\mathrm{kg} \mathrm{ha}^{-1}\right)$ \\
\hline ADR-7010 & $90.21 \mathrm{c}$ & $563.80 \mathrm{c}$ \\
ADR-500 & $110.45 \mathrm{~b}$ & $690.29 \mathrm{~b}$ \\
BRS-1501 & $124.73 \mathrm{a}$ & $776.67 \mathrm{a}$ \\
\hline
\end{tabular}

Means followed by the same letters in the columns are statistically the same by Tukey's test at $5 \%$ probability.

The application of $\mathrm{N}$ doses and $\mathrm{DM}$ yield produced a quadratic effect (Figure 3). A lower DM yield of $\mathrm{N}$ rate $200 \mathrm{~kg} \mathrm{ha}^{-1}$ was probably due to losses of $\mathrm{N}$ by volatilization and leaching and to the decrease of dry matter contents in plants submitted to nitrogen fertilization.

Nitrogen fertilization significantly affected $(\mathrm{p}<0.05)$ DM production (Figure 3). The highest
DM production $\left(3,585.48 \mathrm{~kg} \mathrm{ha}^{-1}\right)$ would be reached by $158 \mathrm{~kg} \mathrm{~N} \mathrm{ha}^{-1}$.

A quadratic effect of nitrogen doses was also observed on NC $\left(\mathrm{kg} \mathrm{ha}^{-1}\right)$ and CP $\left(\mathrm{kg} \mathrm{ha}^{-1}\right)$, as Figures 4 and 5 show. The highest $\mathrm{N}$ accumulation (128.734 $\left.\mathrm{kg} \mathrm{ha}^{-1}\right)$ and crude protein production $\left(804.59 \mathrm{~kg} \mathrm{ha}^{-1}\right)$ would occur with the application of $147 \mathrm{~kg} \mathrm{~N} \mathrm{ha}^{-1}$. 


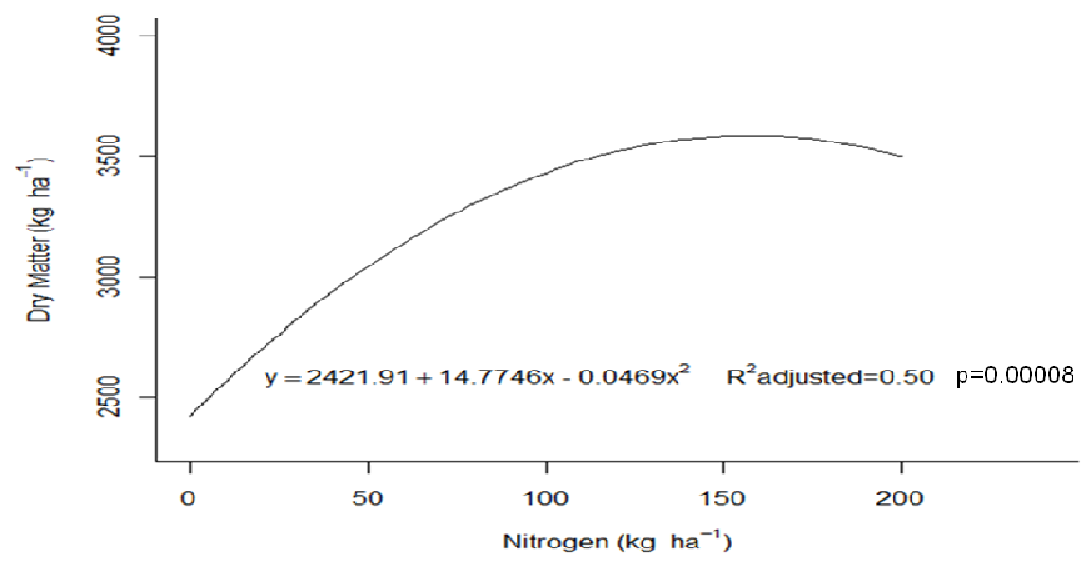

Figure 3. Dry matter yield in response to nitrogen application.

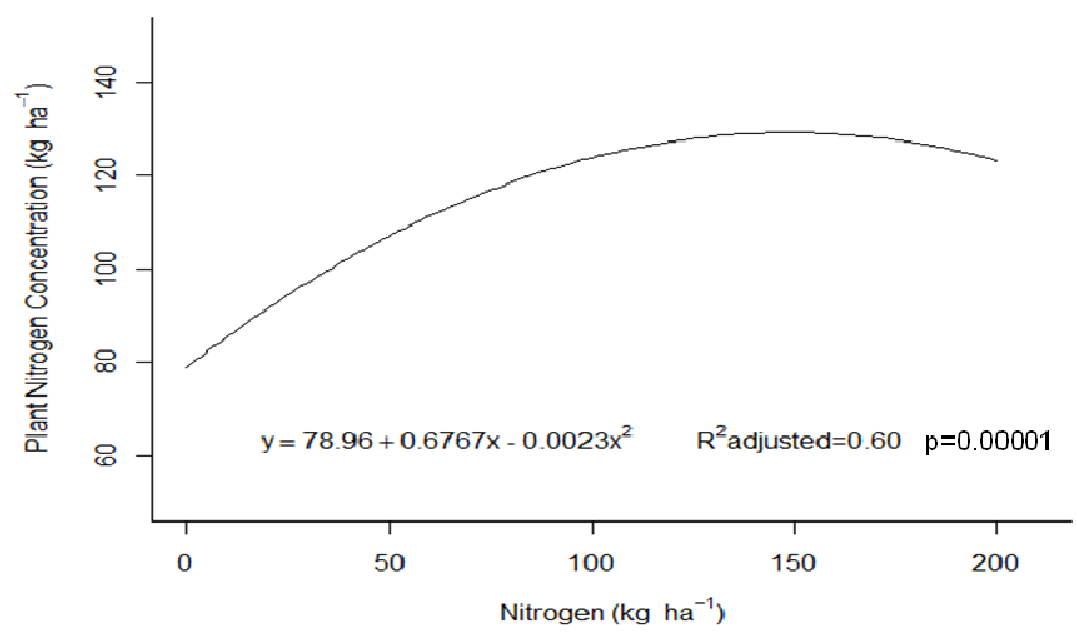

Figure 4. Nitrogen concentration $\left(\mathrm{kg} \mathrm{ha}^{-1}\right)$ in aboveground tissue of pearl millet plants submitted to different nitrogen doses.

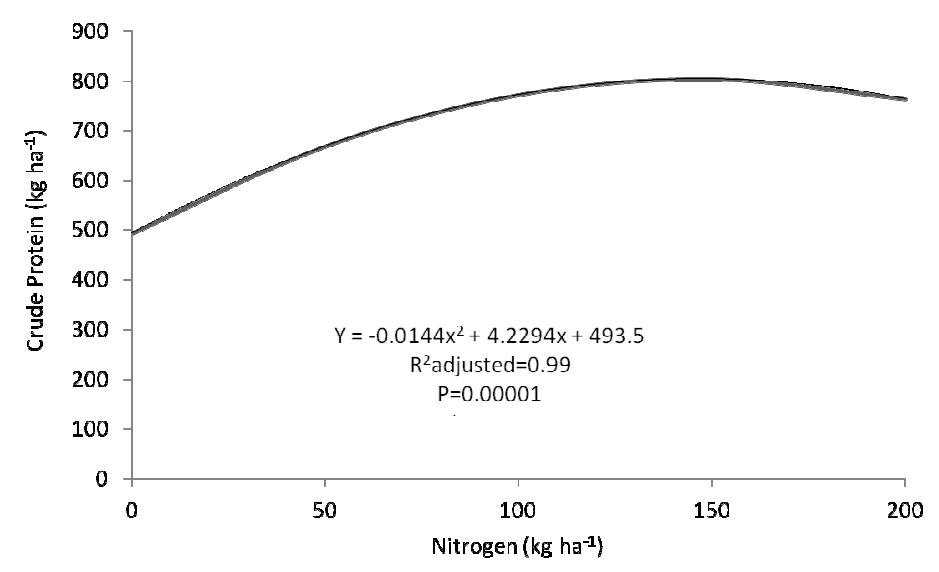

Figure 5. Crude protein production $\left(\mathrm{kg} \mathrm{ha}^{-1}\right)$ in aboveground tissue of pearl millet plants submitted to different nitrogen doses.

Apparent nitrogen conversion efficiency (NCE) and apparent nitrogen recovery (ANR) were significantly affected $(\mathrm{p}<0.05)$ by $\mathrm{N}$ rate. Figure 6
(6A and 6B) show decreasing NCE and ANR as N doses increase. 


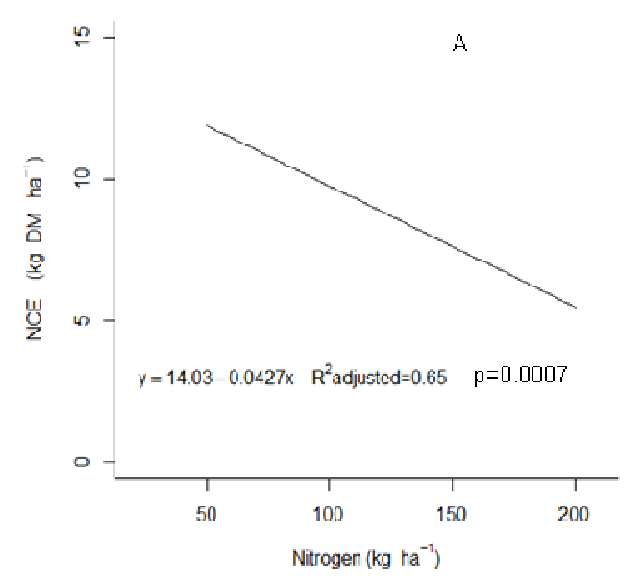

Figure 6. A) Apparent nitrogen conversion efficiency (NCE) and B) apparent nitrogen recovery (ANR) submitted to different nitrogen doses.

\section{DISCUSSION}

Plants sown in December accumulated more $\mathrm{N}$ due to better conditions in temperature, luminosity and water availability, which were factors that raised photosynthesis rates. Rostamza et al. (2011) reported smaller leaf area index (LAI), directly related to the photosynthesis rates, in pearl millet under water stress. Bonfim-Silva et al. (2011) registered that water stress in early development stages compromised dry matter production from maize and pearl millet. Rostamza et al. (2011) also described lower nitrogen conversion efficiency under lower water availability which led to a smaller dry matter production.

Negreiros Neto et al. (2010) studied pearl millet cultivar BRS 1501 and observed a linear response in GM yield with rising $\mathrm{N}$ rates $(0,30,60$ and $120 \mathrm{~kg} \mathrm{ha}^{-1}$ ). Further, Pires et al. (2007) studied plants sown in October and harvested before flowering and reported biomass production of approximately $47,330 \mathrm{~kg} \mathrm{ha}^{-1}$. Costa et al. (2005) planted seeds in January and March and obtained significantly higher DM yields of $6,535.40 \mathrm{~kg} \mathrm{ha}^{-1}$ versus $1,422.20 \mathrm{~kg} \mathrm{ha}^{-1}$, respectively, whereas Calvo et al. (2010) reported that pearl millet harvested 30 days after sowing produced 2,573.20 kg ha- $\mathrm{of}^{-1} \mathrm{DM}$.

Nitrogen uptake is limited by $\mathrm{N}$ availability, but also by the plant's $\mathrm{N}$ demand. Uptake efficiency depends on factors affecting plant growth (varietal characteristics, and the availability of light, water and other nutrients) when related to $\mathrm{N}$ availability (Janssen, 1998).

Results obtained in our research are similar to those in current study and showed that pearl millet planted in the summer had a higher capacity

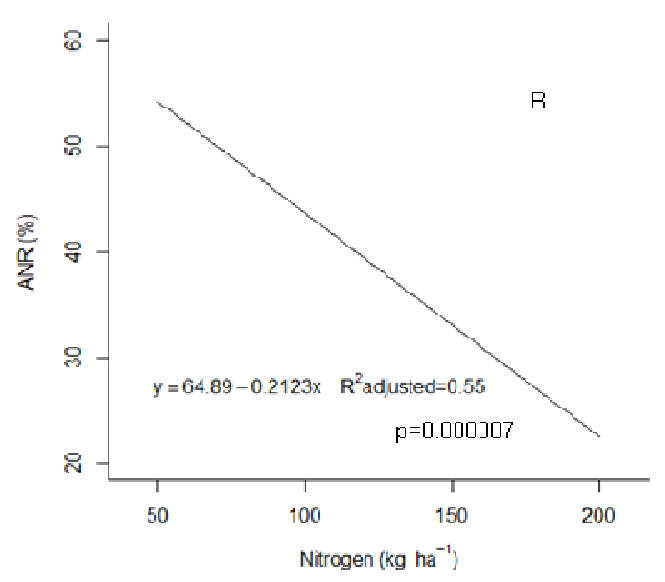

to produce GM and DM when compared to that planted in the off-season.

Results in current study disagree with those by Negreiros Neto et al. (2010) who reported a linear response when nitrogen dose was varied. In fact, they obtained the highest DM yield at dose 120 $\mathrm{kg} \mathrm{ha}^{-1}$ of N. In their studies on elephant grass, Vitor et al. (2009) also registered a linear effect of nitrogen fertilization, with maximum DM yield occurring at a nitrogen rate of $700 \mathrm{~kg} \mathrm{ha}^{-1}$.

In a study on Brachiaria brizantha cv Marandu, Benet et al. (2008) also reported a quadratic effect for DM yield due to $\mathrm{N}$ doses. The application of an increasing $\mathrm{N}$ rate up to $200 \mathrm{~kg} \mathrm{ha}^{-1}$ promoted increased DM production and also raised the content of crude protein and total digestible nutrients. Results in current experiment corroborated the above authors' findings.

The quadratic effect of nitrogen on DM yield may be due to $\mathrm{N}$ losses by volatilization and leaching. According to Janssen (1998), besides the soil's physical characteristics and the weather during the growing season, both uptake efficiency and utilization efficiency depend on the conditions of other growth factors (e.g., crop production potential, availability of other nutrients and water, irradiation). The author states that the improvement of these growth factors will enhance the efficient use of that specific nutrient.

The quadratic effect from nitrogen on DM yield may also be due to a decrease in dry matter content in plants submitted to nitrogen fertilization. Decrease in dry matter content is constantly observed in tropical grasses. In fact, Henriques et al. (2007) and Castagnara et al. (2011) state that the 
above is due to a higher water accumulation in plants to support their larger frame.

Silva et al. (2012) observed a decrease in $\mathrm{DM}$ content and a quadratic effect in nitrogen doses on pearl millet cultivar ADR 300 harvested at 0.20 $\mathrm{m}$. In their research, the cultivar ADR 300 produced $551.79 \mathrm{~kg} \mathrm{DM} \mathrm{ha}^{-1}$ with $100 \mathrm{~kg} \mathrm{~N} \mathrm{ha}^{-1}$ and 489.27 $\mathrm{kg} \mathrm{DM} \mathrm{ha}{ }^{-1}$ with $150 \mathrm{~kg} \mathrm{~N}^{-1}$; dry matter content ranged between $13.9\left(0 \mathrm{~kg} \mathrm{~N} \mathrm{ha}^{-1}\right)$ and $12.5(150 \mathrm{~kg}$ $\mathrm{N} \mathrm{ha}^{-1}$.

According to Costa et al. (2005), DM yield of BRS-1501, harvested during the flowering stage, was $4,458 \mathrm{~kg} \mathrm{ha}^{-1}$, higher than that reported for the same cultivar in current research.

Quadratic responses between $\mathrm{N}$ doses and DM production generally occur in researches evaluating several nutrient levels. According to Dougherty \& Rhykerd (1985), the above occurs due to the fact that after reaching a certain nutrient level, the nitrogen excess may cause an imbalance among nutrients and may intoxicate the plant.

$\mathrm{N}$ dose of $50 \mathrm{~kg} \mathrm{ha}^{-1}$ had the highest NCE, perhaps due to the plant's increase in efficiency when lower nitrogen doses were applied. ANR was also highest at $50 \mathrm{~kg} \mathrm{~N} \mathrm{ha}{ }^{-1}$. This finding demonstrated that ANR rates were higher at lower $\mathrm{N}$ doses. NC and NCE rates in current research corroborated results by Freitas et al. (2005). The authors evaluated Mombasa grass and reported increasing $\mathrm{N}$ concentrations in the plant tissue with increased application of nitrogen fertilizer, reaching maximum accumulation at $280 \mathrm{~kg} \mathrm{ha}^{-1}$.

Apparent $\mathrm{N}$ recovery in current study ranged between $54.27 \%\left(50 \mathrm{~kg} \mathrm{ha}^{-1}\right)$ and $22.43 \%$ $\left(200 \mathrm{~kg} \mathrm{ha}^{-1}\right)$. According to Janssen (1998), between 15 and $20 \%$ of total amount of cereals lies in the roots. Hence, even if recovery is $100 \%$, the measured recovery in the aboveground plant parts cannot exceed the $80-85 \%$ bracket.
Nitrogen conversion efficiency was 11.89 ; 9.76; 7.62 and $5.49 \mathrm{~kg} \mathrm{DM} \mathrm{ha}^{-1}$ for doses 50; 100; 150 and $200 \mathrm{~kg} \mathrm{~N} \mathrm{ha}^{-1}$, respectively. Dias et al. (2000) evaluated coast-cross grass and found that the highest conversion rate occurred with nitrogen dose $100 \mathrm{ha}^{-1}$ which produced $36 \mathrm{~kg}$ of DM per $\mathrm{kg}$ of $\mathrm{N}$ applied. Above results agree with those in current study in which highest DM yields occurred with $\mathrm{N}$ doses 50 and $100 \mathrm{~kg} \mathrm{ha}^{-1}$.

According to Martha Junior et al. (2004), N conversion efficiency of tropical forage plants may reach up to $80 \mathrm{~kg}$ of DM per $\mathrm{kg}$ of $\mathrm{N}$ applied when the pasture is well managed. The authors found an average conversion efficiency of $26 \mathrm{~kg}$ of DM per $\mathrm{kg}$ of $\mathrm{N}$ applied, with the highest efficiency at $\mathrm{N}$ doses up to $150 \mathrm{~kg} \mathrm{ha}^{-1}$.

\section{CONCLUSIONS}

Green matter yield of the three pearl millet cultivars was influenced by nitrogen fertilization, although pearl millet cultivars responded differently to $\mathrm{N}$ doses.

Cultivar BRS-1501 produced the highest quantity of dry matter. Cultivar ADR 500 presented linear response evaluated doses.

Apparent nitrogen conversion efficiency and apparent $\mathrm{N}$ recovery was reduced by increasing $\mathrm{N}$ fertilization doses.

\section{ACKNOWLEDGMENTS}

The authors would like to thank Sementes Adriana and EMBRAPA for supplying the hybrid seeds; the academic funding agency CAPES for its financial support; the Instituto Federal Goiano, Campus Ceres, for providing research facilities; and the Graduate Program in Animal Science of Universidade Federal de Goiás.

RESUMO: O presente trabalho de pesquisa teve como objetivo avaliar o potencial produtivo de massa verde e a massa seca da planta inteira, $\mathrm{N}$ contido na planta, bem como a eficiência de conversão do $\mathrm{N}$ e a recuperação aparente do $\mathrm{N}$ de cultivares de milheto, sob doses de nitrogênio, em diferentes épocas de semeadura no município de Ceres, Goiás. O experimento foi instalado em delineamento de blocos casualizados em esquema fatorial $3 \times 4 \times 2$, constituídos de cultivares de milheto (ADR-7010, ADR-500 e BRS-1501) e doses de N $\left(0,50,100\right.$ e $200 \mathrm{~kg} \mathrm{ha}^{-1}$ de $\mathrm{N}$, aplicados na forma de uréia) o fatorial foi avaliado em duas épocas de semeadura (Dezembro/2010 e Fevereiro/2011). Foram realizados dois cortes em cada época quando as plantas atingiram $0,70 \mathrm{~m}$ de altura. Ocorreu efeito significativo da interação entre cultivares e doses de nitrogênio. A produção de massa verde para a cultivar ADR-7010 aumentou até a dose de $140 \mathrm{~kg} \mathrm{ha}^{-1} \mathrm{de} \mathrm{N}$. Ocorreu efeito quadrático da aplicação das doses de $\mathrm{N}$ na produção de MS, a dose para a máxima produção foi de $158 \mathrm{~kg} \mathrm{ha}^{-1} \mathrm{de} \mathrm{N}$. A quantidade de $\mathrm{N}$ extraído pela planta variou de acordo com a cultivar, onde a BRS-1501 acumulou maiores quantidades de $\mathrm{N}$ na parte aérea. $\mathrm{O}$ máximo teor de nitrogênio contido na parte aérea das plantas de milheto seria atingido com a aplicação de $147 \mathrm{~kg} \mathrm{~N} \mathrm{ha}^{-1}$. A maior eficiência de conversão aparente do nitrogênio ocorreu na dose equivalente a $50 \mathrm{~kg}$ $\mathrm{ha}^{-1}$ de N, com produção de 11,60 kg de MS por kg de N aplicado. A recuperação aparente do nitrogênio foi maior para a dose de $50 \mathrm{~kg} \mathrm{ha}^{-1}$ de N, com máxima de recuperação de $53 \%$. 
PALAVRAS-CHAVE: Épocas de semeadura. Forragem. Nutrição. Pennisetum glaucum. Ureia.

\section{REFERENCES}

BENETT, C. G. S.; BUZETTI, S.; SILVA, K. S.; BERGAMASCHINE, A. F.; FABRÍCIO, J. A. Produtividade e composição bromatológica do capim-marandu a fontes e doses de nitrogênio. Ciência e Agrotecnologia, Lavras, v. 32, n. 5, p. 1629-1636, 2008.

BONFIM-SILVA, E. M.; SILVA, T. J. A.; CABRAL, C. E. A.; KROTH, B. E.; REZENDE, D. Desenvolvimento inicial de gramíneas submetidas ao estresse hídrico. Caatinga, Mossoró, v. 24, n. 2, p. 180186, 2011.

CALVO, C. L.; FOLONI, J. S. S.; BRANCALIÃO, S. R. Produtividade de fitomassa e relação C/N de monocultivos e consórcios de gurandu-anão, milheto e sorgo em três épocas de corte. Bragantia, Campinas, v. 69, n. 1, p. 77-86, 2010. http://dx.doi.org/10.1590/S0006-87052010000100011

CARVALHO, M. M.; SARAIVA, O. F. Resposta do capim gordura (Melinnis minutiflora Beau). A aplicação de nitrogênio em regime de cortes. Revista Brasileira de Zootecnia, Viçosa, v. 16, n. 5, p. 442-454, 1987.

CASTAGNARA, D. D.; ZOZ, T.; KRUTZMANN, A.; UHLEIN, A.; MESQUITA, E. E.; NERES, M. A.; OLIVEIRA, P. S. R. Produção de forragem, características estruturais e eficiência de utilização do nitrogênio em forrageiras tropicais sob adubação nitrogenada. Semina: Ciências Agrárias, Londrina, v. 32, n. 4, p. 1637 1648, 2011.

COSTA, A. C. T.; GERALDO, J.; PEREIRA, M. B.; PIMENTEL, C. Unidades térmicas e produtividade em genótipos de milheto semeados em duas épocas. Pesquisa Agropecuária Brasileira, Brasilia, v. 40, n. 12, p. 1171-1177, 2005. http://dx.doi.org/10.1590/S0100-204X2005001200003

DIAS, P. F.; ROCHA, G. P.; ROCHA FILHO, R. R.; LEAL, M. A. A.; ALMEIDA, D. L.; SOUTO, S. M. Produção e valor nutritivo de gramíneas forrageiras tropicais, avaliadas no período das águas, sob diferentes doses de nitrogênio. Ciência e Agrotecnologia, Lavras, v. 24, n. 1, p. 260-271, 2000.

DOUGHERTY, C. T.; RHYKERD, C. L. The role of nitrogen in forage-animal production. In: HEATH, M. E.; BARNES, R. F.; METCALFE, D. S. (Eds.) Forages: the science of grassland agriculture. Ames: Iowa State University Press, p. 318-325, 1985.

EMBRAPA. Centro Nacional de Pesquisa de Solos (Rio de Janeiro, RJ). Sistema Brasileiro de Classificação de Solos. Rio de Janeiro: Embrapa Solos, 2006, 306p.

FAGUNDES, J. L.; FONSECA, D. M.; MORAIS, R. V. M.; MISTURA, C.; VITOR, C. M. T.; GOMIDE, J. A.; NASCIMENTO JUNIOR, D.; SANTOS, M. E. R.; LAMBERTUCCI, D. M. Avaliação das características estruturais do capim-Braquiária em pastagens adubadas com nitrogênio nas quatro estações do ano. Revista Brasileira de Zootecnia, Viçosa, v. 35, n. 1, p. 30-37, 2006.

FREITAS, K. R.; ROSA, B.; RUGGIERO, J. A.; NASCIMENTO, J. L.; HEINEMAM, A. B.; FERREIRA, P. H.; MACEDO, R. Avaliação do capim mambaça (Panicum maximum Jacq.) submetidos a diferentes doses de nitrogênio. Acta Scientiarum: Agronomy, Maringá, v. 27, n. 1, p. 83-89, 2005.

HENRIQUES, L. T.; COELHO DA SILVA, J. F.; DETMANN, E.; VASQUEZ, H. M.; PEREIRA, O. G. Frações de carboidratos de quatro gramíneas tropicais em diferentes idades de corte e doses adubação nitrogenada. Arquivo Brasileiro de Medicina Veterinária e Zootecnia, Belo Horizonte, v. 59, n. 3, p. 730739, 2007. http://dx.doi.org/10.1590/S0102-09352007000300027 
HERINGER, I.; MOOJEN, E. L. Potencial produtivo, alterações da estrutura e qualidade da pastagem de milheto submetida a diferentes níveis de nitrogênio. Revista Brasileira de Zootecnia, Viçosa, v. 31, n. 2, p. 875-882, 2002, supplement.

JANSSEN, B. H. Efficient use of nutrients: an art of balancing. Field Crops Research, v. 56, n. 1-2, p. 197201, 1998. http://dx.doi.org/10.1016/S0378-4290(97)00130-5

MARTHA JÚNIOR, G. B.; VILELA, L.; BARIONI, L. G.; SOUSA, D. M. G.; BARCELLOS, A. O. Manejo da adubação nitrogenada em pastagens. In: Fertilidade do solo para pastagens produtivas. Piracicaba: FEALQ, p. 155-216, 2004.

MARTUSCELLO, J. A.; FONSECA, D. M. NASCIMENTO JÚNIOR, D.; SANTOS, P. M.; RIBEIRO JUNIOR, J. I.; VIEIRA DA CUNHA, D. N. V; MOREIRA, L. M. Características morfogênicas e estruturais do capim-Xaraés Submetido à Adubação Nitrogenada e Desfolhação. Revista Brasileira de Zootecnia, Viçosa, v. 34, n. 5, p. 1475-1482, 2005.

MELLO, S. Q. S.; FRANÇA, A. F. S.; LANNA, A. C.; BERGAMASCHINE, A. F.; KLIEMANN, H. J.; RIOS, L. C.; SOARES, T. V. Adubação nitrogenada em capim-mombaça: produção, eficiência de conversão e recuperação aparente do nitrogênio. Ciência Animal Brasileira, Goiânia, v. 9, n. 4, p. 935-947, 2008.

MESQUITA, E. E.; PINTO, J. C. Nitrogênio e métodos de semeadura no rendimento da forragem de póscolheita de sementes de milheto [Pennisetum glaucum (L.) R. Br.]. Revista Brasileira de Zootecnia, Viçosa, v. 29 , n. 4, p. 971-977, 2000.

NEGREIROS NETO, J. V.; SANTOS, A. C.; LEITE, R. L. L.; CRUZ, R. S. Análise de diferentes doses de nitrogênio e espaçamentos em milheto no norte do Tocantins. Revista Biotemas, v. 23, n. 4, p. 19-23, 2010. http://dx.doi.org/10.5007/2175-7925.2010v23n4p19

PIRES, F. B.; ASSIS, R. L.; SILVA, G. P.; BRAZ, A. J. B. P; SANTOS, S. C.; VIEIRA NETO, S. A.; SOUSA, J. P. G. Desempenho agronômico de variedades de milheto em razão da fenologia em pré-safra. Bioscience Journal, Uberlândia, v. 23, n. 3, p. 41-49, 2007.

R Development Core Team, 2010. A language and environment for statistical computing. R Foundation for Statistical Computing, Vienna, Austria. ISBN 3-900051-07-0, URL http://www.R-project.org.

ROSTAMZA, M.; MOHAMMAD-REZA, C.; MOHAMMAD-REZA, J.; AHMAD, A. Forage quality, water use and nitrogen utilization efficiencies of pearl millet (Pennisetum americanum L.) grown under different soil moisture and nitrogen levels. Agricultural Water Management, Amsterdam, v. 98, n. 10, p. 1607-1614, 2011. http://dx.doi.org/10.1016/j.agwat.2011.05.014

SILVA, A. G.; FARIA JÚNIOR, O. L.; FRANÇA, A. F. S.; MIYAGI, E. S.; RIOS, L. C.; MORAES FILHO, C. G.; FERREIRA, J. L. Rendimento forrageiro e composição bromatológica de milheto sob adubação nitrogenada. Ciência Animal Brasileira, Goiânia, v. 13, n. 1, p. 67-75, 2012.

http://dx.doi.org/10.5216/cab.v13i1.1434

SILVA, D. J.; QUEIROZ, A. C. Análise de alimentos (Métodos químicos e biológicos). Viçosa, MG: Universidade Federal de Viçosa, 2002, 340p.

VITOR, C. M. T.; FONSECA, D. M.; CÓSER, A. C.; MARTINS, C. E.; NASCIMENTO JÚNIOR, D.; RIBEIRO JÚNIOR, J. I. Produção de matéria seca e valor nutritivo de pastagem de capim-elefante sob irrigação e adubação nitrogenada. Revista Brasileira de Zootecnia, Viçosa, v. 38, n. 3, p. 435-442, 2009. 